\title{
Kaolin consumption and outcome of surgery in women: a comparative study of 263 operations at the Yaoundé Gyneco-Obstetric and Pediatric Hospital
}

\author{
Pascal Foumane $^{1 *}$, Agnès Esiene ${ }^{2}$, Julius Sama Dohbit ${ }^{1}$, Raïssa Carine Ambatta Mbasso ${ }^{1}$, \\ Christiane Nsahlai ${ }^{1}$, Jacqueline Ze Minkande ${ }^{2}$
}

\begin{abstract}
${ }^{1}$ Department of Obstetrics and Gynecology, Faculty of Medicine and Biomedical Sciences (FMBS), The University of Yaoundé 1, Cameroon

${ }^{2}$ Department of Reanimation and Anesthesiology, Faculty of Medicine and Biomedical Sciences (FMBS), The University of Yaoundé 1, Cameroon
\end{abstract}

Received: 05 October 2016

Accepted: 02 November 2016

*Correspondence:

Dr. Pascal Foumane,

E-mail: pfoumane2004@yahoo.fr.

Copyright: (c) the author(s), publisher and licensee Medip Academy. This is an open-access article distributed under the terms of the Creative Commons Attribution Non-Commercial License, which permits unrestricted non-commercial use, distribution, and reproduction in any medium, provided the original work is properly cited.

\begin{abstract}
Background: Kaolin consumption is common in our sub-Saharan Africa. The objective of this study was to assess the effects of kaolin consumption on the outcome of surgery in women.

Methods: It was a cohort study comparing the occurrence of complications during labor among 263 consecutively recruited women who underwent gynecologic or obstetric surgery at the Yaoundé Gyneco-Obstetric and Pediatric Hospital, Cameroon. Sixty of them (22.8\%) declared kaolin consumption before surgery and 203 (77.2\%) who denied having consumed kaolin before surgery.

Results: Kaolin consumption was found to predispose to postsurgical infections ( $R R=3.03$; $\mathrm{IC}=1.82-5.05)$.

Conclusions: Kaolin geophagia should be identified before surgery to prevent related postsurgical infections. A systematic ban of kaolin consumption is also recommended.
\end{abstract}

Keywords: Cameroon, Kaolin, Outcome, Postsurgical infections, Surgery

\section{INTRODUCTION}

Kaolin geophagia is a worldwide practice, particularly in Africa and South-America. ${ }^{1,2}$ In sub-Saharan Africa, rates as high as $50 \%$ to $84 \%$ of pregnant women consuming kaolin have been documented. ${ }^{1,2}$ Cultural reasons and gastric disorders are the main explanations of the higher frequencies of this abnormal nutritional behavior in pregnant women. $^{2-4}$

To date, little is known about the surgical complications commonly occurring in kaolin-consuming women, especially in sub-Saharan Africa. The objective of this study therefore was to assess the effects of kaolin consumption on the outcome of gynecologic and obstetric surgeries.

\section{METHODS}

This was a cohort study comparing the occurrence of surgical complications between 60 women who declared habitual kaolin consumption (exposed group) to 203 women who denied kaolin consumption (non exposed group). Both groups were consecutively recruited, from December $15^{\text {th }} 2014$ to April $30^{\text {th }} 2015$, at the Yaoundé Gynaeco-Obstetric and Pediatric Hospital, Cameroon. After the approval of the protocol by the ethical committee of the hospital, all women admitted for elective or emergency surgery and who gave their informed consent, were recruited into the study. Occasional kaolin consumers and women who underwent minor surgeries such as intrauterine curettage or intrauterine aspiration, marsupialization and cervical 
cerclage were excluded. The enrolled women were examined on admission and followed by an obstetrician/gynecologist or a resident in obstetrics and gynecology. A pretested questionnaire was administered and the women were followed up from inclusion into the study to the post-operative visit. The variables studied were: socio-demographic characteristics (age, parity, profession, marital status, level of education), characteristics of kaolin consumption (duration, quantity, frequency, reason), personal and family history, characteristics of the surgery (type, indication) hemoglobin level, postsurgical complications (infection, hemorrhage, bowel occlusion, deep venous thrombosis).

For the calculation of the minimal sample size for each group, it was assumed that kaolin consumption would multiply by three the rate of postsurgical infections from 23,2\% reported by HENTCHOYA et al. at the Yaoundé University Teaching Hospital. ${ }^{5}$ The calculated minimal sample size using the formula proposed by SCHULZ et al was 43 subjects for each group with chosen precision and power respectively of $5 \%$ and $90 \%{ }^{6}$ Statistical analysis was done using Epi info 3.5.4 and SPSS 12.0 software. The difference was statistically significant for Pvalue $<0.05$. The Pearson's Chi square and the Fisher's exact test were used to compare proportions. The difference was statistically significant for $\mathrm{P}$-value $<0.05$. Relative risk (RR) was calculated to measure the association between kaolin consumption and the outcome of gynecologic and obstetric surgery.

\section{RESULTS}

Two hundred and sixty-three women who met the inclusion criteria during the recruitment period were included in the study. Among them, 60 (60/263; 22.8\%) declared non-occasional kaolin consumption before surgery (exposed group) while 203 (203/263; 77.2\%) did not consume kaolin (non-exposed group).

Table 1: Significant pre-inclusion variables between the exposed $(\mathrm{N}=60)$ and the non-exposed $(\mathrm{N}=203)$ groups.

\begin{tabular}{|llll|}
\hline Variable & $\begin{array}{l}\text { Kaolin } \\
\text { consumption } \\
\text { n (\%) }\end{array}$ & $\begin{array}{l}\text { No kaolin } \\
\text { consumption } \\
\text { n (\%) }\end{array}$ & P \\
\hline $\begin{array}{l}\text { (35-40) years } \\
\text { age group }\end{array}$ & $5(8.3)$ & $46(22.7)$ & 0.0081 \\
\hline Single & $33(55.0)$ & $82(40.4)$ & 0.0321 \\
\hline Married & $26(43.3)$ & $119(58.6)$ & 0.0261 \\
\hline Gravidity 0 & $6(10.0)$ & $6(2.9)$ & 0.0326 \\
\hline Gravidity 5 & $2(3.3)$ & $25(12.1)$ & 0.0297 \\
\hline
\end{tabular}

The analysis of the pre-inclusion variables (Table 1) showed that single women and nulligravidae were significantly involved in kaolin consumption, while women aged between 35 and 40 years, married or who had five previous pregnancies were significantly represented in the non-exposed group. Other preinclusion variables, such as the presence of anemia preoperatively $(\mathrm{P}=0.0622)$, showed no significant association with kaolin consumption.

In the exposed group, the mean duration of kaolin consumption before surgery was $52.2 \pm 64.9$ months, with a duration lasting more than a year in $53.3 \%$ of the women included (Table 2). Kaolin consumption was at least weekly in $86.6 \%$ of patients. At the same time, $41.7 \%$ of them ingested more than $100 \mathrm{~g}$ of kaolin per week. Desire $(73.3 \%)$ and nausea or vomiting $(31.7 \%)$ were the main reasons given to justify kaolin geophagia in this study.

Table 2: Characteristics of kaolin consumption in the exposed group $(\mathrm{N}=60)$.

\begin{tabular}{|ll|}
\hline Characteristic & n $(\%)$ \\
\hline Duration of consumption & \\
\hline$<3$ months & $13(21.7)$ \\
\hline$(3-12)$ months & $15(25.0)$ \\
\hline$\geq 12$ months & $32(53.3)$ \\
\hline Frequency of consumption & \\
\hline Daily & $23(38.3)$ \\
\hline Weekly & $29(48.3)$ \\
\hline Monthly & $8(13.4)$ \\
\hline Quantity consumed & \\
\hline$<100$ g/week & $35(58.3)$ \\
\hline$\geq 100$ g/week & $25(41.7)$ \\
\hline Reason for consumption & \\
\hline Desire & $44(73.3)$ \\
\hline Nausea or vomiting & $19(31.7)$ \\
\hline Gastric pain & $1(1.7)$ \\
\hline Attractive odor & $1(1.7)$ \\
\hline No reason & $3(5.0)$ \\
\hline
\end{tabular}

Table 3: Comparison of the types of surgeries between the exposed $(\mathrm{N}=60)$ and the non-exposed $(\mathrm{N}=203)$ groups.

\begin{tabular}{|llll|}
\hline $\begin{array}{l}\text { Type of } \\
\text { surgery }\end{array}$ & $\begin{array}{l}\text { Kaolin } \\
\text { consumption } \\
\mathrm{n}(\%)\end{array}$ & $\begin{array}{l}\text { No kaolin } \\
\text { consumption } \\
\mathrm{n}(\%)\end{array}$ & $\begin{array}{l}\mathrm{P} \\
\text { value }\end{array}$ \\
\hline $\begin{array}{l}\text { Cesarean section } \\
38(63.3)\end{array}$ & $151(74,4)$ & 0.1311 \\
\hline Laparoscopy & $1(1.7)$ & $4(2.0)$ & 0.8799 \\
\hline $\begin{array}{l}\text { Laparotomy for } \\
\text { ectopic } \\
\text { pregnancy }\end{array}$ & $4(6.7)$ & $20(9.9)$ & 0.4592 \\
\hline $\begin{array}{l}\text { Ovarian } \\
\text { cystectomy }\end{array}$ & $4(6.7)$ & $3(1.5)$ & 0.0444 \\
\hline Myomectomy & $6(10.0)$ & $11(5.4)$ & 0.2072 \\
\hline Hysterectomy & $5(8.3)$ & $9(4.4)$ & 0.2409 \\
\hline Mastectomy & $2(3.3)$ & $5(2.4)$ & 0.9657 \\
\hline
\end{tabular}

The most common type of surgery in the study population was cesarean section constituting $71.7 \%$ of the operations. Apart from a slight statistical difference 
between the two groups as far as ovarian cystectomies were concerned, there was no other significant difference in terms of the types of surgeries done in our patients (Table 3). Women who consumed kaolin during their pregnancy had a higher risk (Table 4) of postsurgical infections ( $\mathrm{RR}=3.03 ; \mathrm{IC}=1.82-5.02)$. These infections included parietal suppurations, endometritis and pulmonary infections. The other post-operative variables studied were not significantly associated with kaolin consumption.

Table 4: Comparison of the post-operative complications between the exposed $(\mathrm{N}=60)$ and the non-exposed $(\mathrm{N}=203)$ groups.

\begin{tabular}{|lllll|}
\hline $\begin{array}{l}\text { Post-operative } \\
\text { complications }\end{array}$ & $\begin{array}{l}\text { Kaolin consumption } \\
\text { n }(\%)\end{array}$ & $\begin{array}{l}\text { No kaolin consumption } \\
\text { n(\%) }\end{array}$ & RR (95\% CI*) & P \\
\hline Anemia & $4(18.2)$ & $18(81.8)$ & $0.78(0.31-1.96)$ & 0.4068 \\
\hline Infections & $7(63.6)$ & $4(36.4)$ & $3.03(1.82-5.02)$ & 0.0036 \\
\hline Bowel occlusion & $1(33.3)$ & $2(66.7)$ & $1.47(0.29-7.39)$ & 0.5417 \\
\hline Deep venous thrombosis & $0(0)$ & $1(100)$ & $1.11(0.04-27.01)$ & 0.7718 \\
\hline
\end{tabular}

\section{DISCUSSION}

According to our findings, $22.8 \%$ of the enrolled women consumed kaolin at least once monthly before surgery. This figure is below the $50 \%$ to $84 \%$ prevalence of kaolin consumption reported respectively in Nigeria and Uganda in pregnant women. ${ }^{2}$

We propose an explanation for this rate in the fact that we included non-pregnant women undergoing gynecologic surgery and excluded occasional kaolin consumers in the study. As a matter of fact, the strong desire for kaolin ingestion by pregnant women is known, and explained mostly by cultural reasons and gastric discomfort relief (7-8). However, rates reported in South-America are similar to ours. ${ }^{9}$

Kaolin consumption during pregnancy was found in this study to predispose to postsurgical infections. To the best of our knowledge, this has never been documented in the available literature. An explanation for this predisposition to postsurgical infections could be found in the iron deficiency anemia documented in kaolin consumers, possibly due to induced hypoxia that may result in tissue ischemia and local immune impairment. ${ }^{10}$

The postsurgical infections identified in this study as a result of kaolin consumption are mainly explained by iron deficiency anemia; however this was not specifically objectified in our findings. This might has given some bias to our results.

\section{CONCLUSION}

Kaolin consumption predisposes to post-surgical infections after gynecologic or obstetric surgeries. Kaolin geophagia should be identified before surgery to prevent related postsurgical infections. A systematic ban of kaolin consumption is also recommended.
Funding: No funding sources

Conflict of interest: None declared

Ethical approval: The study was approved by the Institutional Ethics Committee

\section{REFERENCES}

1. Seyrane Y, Favrat B, Patrick B, Michel C. Iron deficiency anemia on Geophagy in a rich country? Rev Med Suisse. 2012;(8):604-6.

2. Njiru H, Elchalal U, Paltiel O. Geophagy during Pregnancy in Africa: A Literature Review. Obstet Gynecol Surv. 2011;66(7):452-9.

3. Geissler PW, Prince RJ, Levene M. perceptions of soils eating and anemia among pregnant women on the Kenyan coast. Soc Sci Med. 1999;48:1069-79.

4. Izugbara CO. The cultural context of geophagy among pregnant and lactating Ngwa women of Southeastern Nigeria. Afr Anthropol. 2003;10(2):180-98.

5. Hentchoya R, Simo Moyo J, Afane EA, Simeu C, Takouefou B. Postoperative infectious morbidity in obstetric and gynecologic surgery at the Yaoundé University Teaching Center. Clin Mother Child Health. 2007;4(2):723-31.

6. Schulz KF, Grimes DA. Sample size calculations in randomized trials: mandatory and mystical. Lancet. 2005;365:1348-53.

7. Murray HH. Traditionnal and new applications for kaolin, smectite and polygorskite: a general overview. Appl Clay Sci. 2000;17:207-14.

8. Young SL, Khalfan SS, Farag TH, Kavle JA, Ali SM, Hajji H. Association of pica with anemia and gastrointestinal distress among pregnant women in Zanzibar, Tanzania. Am J Trop Med Hyg. 2010;83:144-7. 
9. Simpson M, Mull JD, Longley E, East J. Pica during pregnancy in low-income women born in Mexico. West J Med. 2000;173(1):20-5.

10. Young SL. Pica in pregnancy: new ideas about an old condition. Annu Rev Nutr. 2010;30:403-22.
Cite this article as: Foumane P, Esiene A, Dohbit JS, Ambatta Mbasso RC, Nsahlai C, Ze Minkande J.

Kaolin consumption and outcome of surgery in women: a comparative study of 263 operations at the Yaoundé Gyneco-Obstetric and Pediatric Hospital. Int J Reprod Contracept Obstet Gynecol 2016;5:4216-19. 